\title{
Some Features of the Development of AMD and Other Diseases of the Posterior Pole Associated with the Virus Carrier and the Novel Coronavirus Disease COVID-19
}

\author{
Sergey Aleksandrovich Ignatiev ${ }^{1}$, Igor' Borisovich Alekseev ${ }^{2,3}$, Sergey Petrovich Kazakov ${ }^{3,4}$, \\ Yuliya Arkadievna Nam ${ }^{5, *}$, Aleksandr Ivanovich Listratov ${ }^{3}$ \\ ${ }^{1}$ Consulting Department, City Clinical Hospital Named by S. P. Botkin, Department of Health, Moscow, Russian Federation \\ ${ }^{2}$ State Clinical Hospital Named by S. P. Botkin, Moscow City Ophthalmological Center, Moscow, Russian Federation \\ ${ }^{3}$ Federal State Budgetary Educational Institution of Further Professional Education Russian Medical Academy of Continuous Professional \\ Education, Ministry of Healthcare of the Russian Federation, Moscow, Russia Federation \\ ${ }^{4}$ Main Military Clinical Hospital Named After N. N. Burdenko, Moscow, Russia Federation \\ ${ }^{5}$ Branch №2, Federal Budgetary Institution of Healthcare, Medical Rehabilitation Centre, Ministry of Economic Development of Russia, \\ Moscow, Russian Federation
}

Email address:

yuliyanam@rocketmail.com (Y. A. Nam)

${ }^{*}$ Corresponding author

\section{To cite this article:}

Sergey Aleksandrovich Ignatiev, Igor' Borisovich Alekseev, Sergey Petrovich Kazakov, Yuliya Arkadievna Nam, Aleksandr Ivanovich Listratov. Some Features of the Development of AMD and Other Diseases of the Posterior Pole Associated with the Virus Carrier and the Novel Coronavirus Disease COVID-19. International Journal of Clinical and Experimental Medical Sciences.

Vol. 7, No. 5, 2021, pp. 127-137. doi: 10.11648/j.ijcems.20210705.11

Received: August 16, 2021; Accepted: September 7, 2021; Published: September 27, 2021

\begin{abstract}
This article highlights main aspects of pathogenesis of age-related macular degeneration (AMD) and the connection between SARS-CoV-2 and diseases of the posterior pole of the eyes. Background: A novel coronavirus disease COVID-19 is actual nowadays due to its multiple organ damage, including eye tissues. Retina is also a target organ. AMD is the most common cause of central vision loss and its development is connected not only with ageing, but also with some other factors. Last years ophthalmological community considers virus infection to be a predictor and trigger for developing of AMD. Objective: Several theories have been proposed for the development of AMD. The most common theories are vascular due to pathogenetically significant decrease in blood flow in the pool of the carotid arteries; metabolic disorders (systemic and local); oxidative stress in endothelial cells; hereditary predisposition. Inflammation as a pathogenetic mechanism appeared in a novel light of discoveries in developing of not only AMD, but also some other eye diseases. The connection between SARS-CoV-2 and diseases of the posterior pole known nowadays are conjunctivitis, central retinal vein occlusion, isolated inflammatory optic neuritis, acute bilateral demyelinating optic neuritis. Thus, the question is still open. Conclusion: no single theory of the development of AMD can absolutely explain the diversity of pathological changes in of the retina and choroid tissues. Further study of the role of each factor of pathogenesis- from molecular to tissue will allow the development of fundamentally novel and perspective directions of AMD therapy.
\end{abstract}

Keywords: Age-related Macular Degeneration, COVID-19, Virus Infection

\section{Introduction}

Despite all the advances in modern medicine, pathology of the posterior pole of the eye including AMD is the most common cause of decrease and loss of central vision [1-6].
The fact that a novel coronavirus disease COVID-19 is spread around the world is especially actual nowadays. Russian ophthalmologists and community of ophthalmologists all over the world consider AMD as a multifactorial disease and its development is influenced by 
age, hereditary factors, ethnicity, smoking and other factors [7-9].

Age-related macular degeneration (AMD) is a disease of the macula characterized by presenting of one or more of the following changes [1]:

Presence of at least intermediate-size drusen $(>63 \mu \mathrm{m}$ in diameter)

Retinal pigment epithelium (RPE) abnormalities such as hypopigmentation or hyperpigmentation

Presence of any of the following features: geographic atrophy of the RPE, choroidal neovascularization ([CNV] exudative, wet), polypoidal choroidal vasculopathy (PCV), reticular pseudodrusen, or retinal angiomatous proliferation

Age-related macular degeneration is a leading cause of severe, irreversible vision impairment in developed countries. The number of individuals affected by advanced forms of AMD in at least one eye will increase to nearly 3 million by 2020 , based on demographical data of the aging population in the United States [10].

The question of effective, pathogenetically justified methods of treatment is still open due to variety of clinical manifestations: the development of soft and hard drusen, the formation of geographical atrophy, detachment of the pigment epithelium and neuroepithelium (both serous and hemorrhagic), as well as the lack of consensus on the causes and mechanisms of the appearance and development of this pathology.

The aim of the study is to compare the development of dystrophic and other diseases in the posterior pole of the eye using the example of the carrier of cytomegalovirus virus, taking into account the increasing spread of the new coronavirus infection and its ophthalmological manifestations, insufficiently studied pathogenesis of this disease and relying on the clinical manifestations published in the existing medical literature.

\section{Literature Review}

Several theories have been proposed for the development of AMD. According to one of them, there is a pathogenetically significant decrease in blood flow in the pool of the carotid arteries predominantly in the elderly population. As a result, it affects the reduction of perfusion pressure in the arteries of the eye, including those in the system of the short posterior ciliary arteries. It should be noted that the tropism of the central parts of the macular zone (the area between the fovea centralis and foveola) is only provided by the nutrients diffusion from the choriocapillary layer of the choroid in the absence of retinal vessels (foveolar avascular zone). This fact, perhaps, makes this retinal zone the most vulnerable to the listed age-related changes [11, 12]. Hemodynamic disturbances in the choroidal circulation can also be associated with involutional changes: decrease in the thickness of the choriocapillary layer (from $200 \mu \mathrm{m}$ in young people to $80 \mu \mathrm{m}$ by the age of 90 years), an increase in intercapillary spaces, a decrease in the lumen of blood vessels, a reduction of number of fenestrated capillaries [13-
16]. The consequence of the listed processes is deprivation of adequate oxygen supply of RPE and the photoreceptor layer, a decrease in passive diffusion of organic substances with a predominance of oxidative processes and the induction of apoptosis of RPE. Due to these processes a disruption of the normal processes of heterophagy and autophagy (absorption, processing and excretion of spent fragments of photoreceptors) occurs [17].

Systemic hemodynamic disorders can play an equally important role in the development of AMD. In older patients, there is a significant lesion of the vessels supplying the brain and heart, which leads to a decrease in blood flow in the main arteries of the head and possibly changes regional and cerebral hemodynamics in AMD [1]. E. P. Gvarishvili [18] observed the presence of a blood flow deficiency in the middle cerebral artery in patients with dry AMD. E. A. Abdullaeva [19] registered blood circulation changes in the pool of the internal carotid artery and vertebral arteries. The development of hemodynamic disorders is possible in case of arterial hypotension, leading to a significant decrease in trophic processes in the retina and choroid [20, 21]. A number of researchers note a combination of degenerative changes in the macular region with atherosclerotic lesions of the cerebral and coronary vessels. Authors indicate the similarity of the processes of atherosclerotic plaque formation and drusenogenesis [22-24].

Another group of factors in the pathogenesis of AMD are metabolic disorders (systemic and local), which result in oxidative stress of RPE [7, 25-27]. According to a number of authors, oxidative stress in endothelial cells is the cause of not only aging, but also an important pathogenetic component of some serious diseases like arterial hypertension, atherosclerosis or diabetes mellitus. Oxidative stress is also the cause of AMD [7, 25-29]. The retina suffers from the accumulation of oxidation products more than any other tissues, being a nervous structure with a high level of metabolism [7]. Oxidative stress develops as a result of a chronic imbalance between the formation of reactive oxygen species as a result of oxidative phosphorylation processes and the activity of the antioxidant system (carotenoids, vitamins A, C, E, superoxide dismutase, catalase, peroxidase, etc.) [30]. By counteracting reactive oxygen species (superoxide and peroxide anions) and free radicals (carboxyethylpyrrole, malondialdehyde, 4-hydroxynonenal), the antioxidant system protects the cell from damage of proteins, lipids, and DNA $[17,31,32]$. However, low activity of antioxidants and /or excessive formation of free radicals, low-density lipoproteins and end products of glycolysis, accumulating in the intercellular space and inside the lysosomes of RPE, lead to lysosomal dysfunction. With prolonged exposure, they lead to apoptosis of RPE cells, damage Bruch's membrane (BM) and choriocapillaries. Suppression of the vital activity of some RPE cells, in turn, leads to impaired absorption and processing by other cells of various kinds of "waste" (mainly the outer segments of photoreceptors) and the accumulation of unprocessed material in other healthy epithelial cells and under the basal lamina of RPE. This circumstance is 
considered to be a key point in drusen formation. According to G. Hageman et al. [33], Bikbov et al. [7], drusen are a metabolic product of RPE cells and a biomarker of AMD.

According to the results of other studies, the composition of druses is quite diverse and includes lipid, carbohydrate, protein, and cellular components [33-35]. One of the main components of drusen is lipofuscin, or "aging pigment", which belongs to the group of $\mathrm{c}$. The basis of lipofuscin is represented by N-retilidin-N-retinylethanolamine (A2E), which can disrupt the functioning of lysosomes and release pro-apoptotic proteins from mitochondria, as well as block oxidative phosphorylation enzymes. This leads to an increase in reactive oxygen species and maintenance of oxidative stress [36-39]. In addition, A2E activates the production of vascular endothelial growth factor (VEGF) by pigment epithelial (PE) cells, which, in turn, leads to the formation of choroidal neovascularization and the development of a wet form of AMD [36]. Induction of VEGF expression and secretion by $\mathrm{PE}$ cells due to oxidative stress has been demonstrated experimentally [40, 41]. Oxidative stress can also cause the secretion of interleukin-6 (IL-6) by PE cells, which promotes an increase in VEGF secretion (autocrine regulation of VEGF secretion) [42].

VEGF is a potent mitogen for PE cells, endothelial cells and neuroepithelium in terms of unfavorable conditions. It prevents apoptosis in cells, activates survival factors like Bcl2, A-1, IAP, Akt, Erk (inhibitors of apoptosis) [43, 44]. Thus, oxidative stress induces the expression of VEGF by PE cells, which supports them to survive in the attack of stressgenerating agents. However, chronic stress causes an inflammatory response and the development of AMD. Thus, VEGF is an autocrine survival factor of retinal PE under conditions of oxidative stress; however, if PE cells are unable to withstand stress, they undergo apoptosis, which leads to the development of various diseases [44]. Therefore, antiVEGF therapy for AMD can cause the regression of new vessels and inhibit the repair of the PE barrier, which limits neovascularization, so, prolonged anti-VEGF therapy can damage photoreceptors [43, 44]. The studies by S. Byeon et al. [45] showed that antiVEGF therapy may have negative consequences in some patients. This fact probably indicates to the secondary role of VEGF in the pathogenesis of AMD and its negative impact on the course of the disease only in combination with other pathogenic factors.

Another factor that has recently been assigned is an increasing role of the hereditary predisposition in the pathogenesis of AMD. This fact is confirmed by studies of families with cases of AMD, as well as by the study of the formation and course of macular pathology in twins [44, 4648]. In 2005 G. Hageman et al. identified the complement factor $\mathrm{H}(\mathrm{CFH})$ gene, its mutation is regarded as the main risk factor for the development of AMD [49]. The CFH gene encodes the complement factor $\mathrm{H}$ (known as beta-1H protein) - a plasma protein from the complement system that is involved in regulating the immune response. The main stage of any complement cascade is the splitting of protein $\mathrm{C} 3$, the most important component of the complement system, by
C3-convertase into 2 fragments (C3a and $\mathrm{C} 3 \mathrm{~b})$. The $\mathrm{C} 3 \mathrm{~b}$ molecule binds to another complement component, factor $\mathrm{B}$. Due to this process the $\mathrm{C} 3 \mathrm{bBb}$ complex ( $\mathrm{C} 3$ convertase) is synthesized [50].

Splitting of C3 is essential for the elimination of pathogens, however, under normal conditions, there is a mechanism that keeps the process of cleavage of $\mathrm{C} 3$ at a "disabled level" in order to avoid excessive production of C3 convertase [50]. The presence of a deterrent mechanism, in this case $\mathrm{CFH}$, means that there is a positive feedback effect, which can potentially get out of control. Complement factor $\mathrm{H}$ binds to protein $\mathrm{C} 3 \mathrm{~b}$ and, by limiting its function, accelerates the breakdown of $\mathrm{C} 3$ convertase. This factor also acts as a cofactor for complement factor I (another $\mathrm{C} 3 \mathrm{~b}$ inhibitor). It is a regulatory protein of the complement system that works both in serum and on the cell surface, and has an antiinflammatory effect [50].

The defective $\mathrm{CFH}$ gene encodes a variant with insufficient ability to inactivate the complement system adequately, resulting in a high concentration of complement factors. Subsequently, a damage of own cells and tissues happens [51]. Polymorphism of the $\mathrm{CFH}$ gene, manifested in the replacement of the nitrogenous base of thymine by cytosine in exon 9, increases the risk of AMD. Mutations in the gene encoding $\mathrm{CFH}$ are associated with an increased level of C-reactive protein in the choroid, which can induce chronic inflammation and development of AMD [51].

Inflammation as a pathogenetic mechanism appeared in a new way in the light of discoveries, following for the identification of the $\mathrm{CFH}$ gene. In particular, it has been shown that mutations at various loci encoding complement factors (complement factor B, complement component 2 and 3 ), in combination with other risk factors exacerbate the course of AMD compared with those who are not carriers of defective genes. This data influenced on the changing of ideas about the pathogenesis of AMD [51, 52]

P. Penfold et al. were the first who suggested that AMD is a consequence of chronic inflammation. They found the accumulation of macrophages, fibroblasts, lymphocytes and mast cells in damaged areas in Bruch's membrane with electronic microscopy. Thus the authors have determined the role of immunocompetent cells in the formation of neovascular membrane [53]. These cells are capable of producing inflammatory cytokines: interleukin-1 $\beta$ (IL-1 $\beta$ ), tumor necrosis factor $\alpha$ (TNF- $\alpha)$, interleukin-8 (IL-8), interleukin-18 (IL-18), etc. They launch a cascade of immune reactions and lead to an increase functional activity of neutrophils, including the number of expression of adhesion molecules, the formation oxygen radicals and the release of lysosomal enzymes [50, 54-56]. Inflammatory mediators can target PE cells, causing uncontrolled inflammatory response and leading to dysfunction of the RPE [57]. PE cells, along with immune cells, are capable of producing IL- $1 \beta$ and IL-18 under unfavorable conditions (oxidative stress, ischemia, hypoxia) bypassing the classical pathway of protein secretion, forming a pathological immune pattern. The biologically inactive form of the cytokine first accumulates in the 
cytoplasm of PE cells, and then moves to specializeda secretory lysosomes, where the inactive form of the enzyme caspase-1 (procaspase-1) is located. Then procaspase-1 is activated with the formation of an active enzyme under the influence of several cytoplasmic proteins that form the socalled inflammasome $[17,58]$.

Inflammasome is not a true cellular organelle, but is a functional formation of several cytoplasmic proteins belonging to the group of intracellular recognition receptors (NOD-like receptors). These proteins include cryopyrin cytosolic protein NLRP3 and its known ligands are the viral genome and the products of oxidative stress. Activation of cryopyrin, like other protein fractions of inflammasomes, leads to the degradation of the precursors of IL-1 $\beta$ and IL-18, to the formation of active forms of these cytokines with the participation of caspase- $1[17,58,59]$. It is shown that so called NLRP3 inflammasomes are also present in PE cells and under unfavorable conditions are able to start a cascade of reactions leading to lesion and dysfunction of PE [60-62]. In addition to activating inflammasome proteins (the first of the intracellular signaling pathway), pathogens (endogenous and exogenous irritants with biological, chemical and physical origin) interact with Toll-like receptors (TLR) of the membrane and intracellular Nod-like receptors (NLR), not related to proteins by inflammasomes. As a result of this interaction, the NFKB transcription factor is activated, then it is transferred into the nucleus of the immune cell, and the expression of genes of the IL-1 family cytokines (IL-1 $\beta$, IL$18)$ is triggered [58].
Then activation of the transcription factor $\mathrm{NF \kappa B}$ and increased expression of IL-1 $\beta$ induce the expression of VEGF [63]. This effect can be enhanced in the case of simultaneous synthesis of IL- $1 \beta$, TNF- $\alpha$ and interferon $\gamma$ (IFN- $\gamma$ ) [64]. J. Jonas et al. showed that when the choroidal neovascular membrane $(\mathrm{CNV})$ is already formed in the subretinal space, immune inflammation continues to be active in the area of PE cells, which are capable of producing the cytokine MCP-1 (monocyte chemoattractant protein 1). MCP-1 is a chemoattractant for monocytes / macrophages and lymphocytes, and its concentration correlates with the degree of macular edema [65]. Macrophages and neutrophils migrate to the CNV region and produce VEGF and other angiogenic factors, while dendritic cells produce VEGF-R (VEGF receptor) [44, 58]. In addition, H. Huang et al. revealed the importance of VEGF as a chemoattractant for involvement of retinal microglia to the CNV focus. In studies on mice, the authors observed the migration of microglial cells (retinal own macrophages) from the inner retinal layers to the outer ones in an induced AMD model. Thus authors determined the ability of retinal tissue to independently respond by activating microglia in response to injury [66].

\section{The Connection Between AMD and Cytomegalovirus (CMV)}

The interaction of cytomegalovirus and a macroorganism can be schematically represented as following (Figure 1).

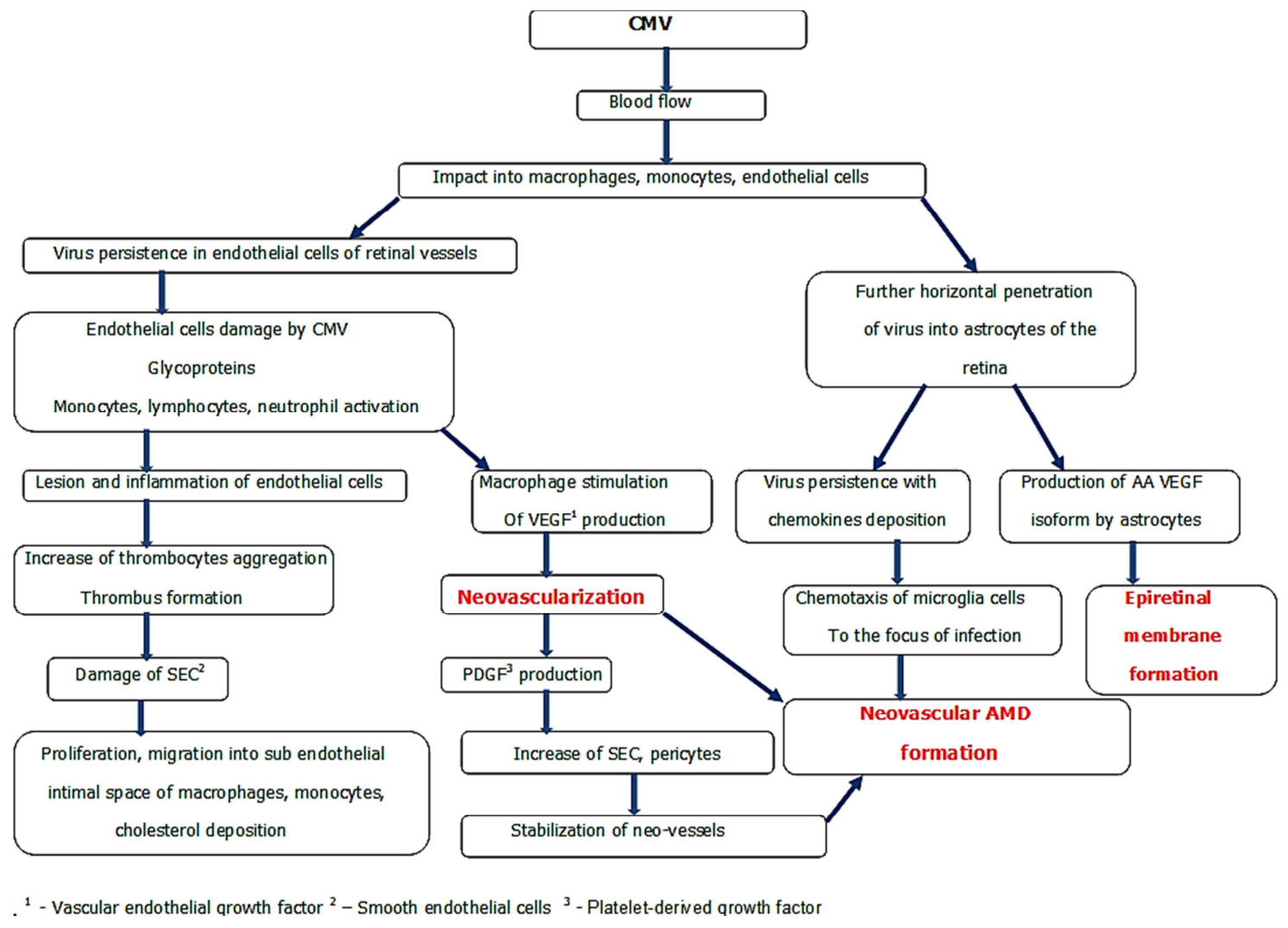

Figure 1. Pathogenesis of AMD development according to connection with CMV. 
Three main elements of clinical manifestations from the figure are:

Thrombus formation with subsequent deposition of cholesterol (development of atherosclerotic lesion).

Ischemia (hypoxia) of the retina and brain tissue.

Fibrosis (epiretinal fibrosis).

Moreover, all these components of the clinical picture aggravate each other.

Primary human infection with Cytomegalovirus (CMV) usually occurs in childhood and is accompanied by the formation of a permanent latent infection of hematopoietic cells, the precursors of monocytes [67]. After maturation of the infected monocytes, CMV genes are expressed and the cell becomes aggressive [67-69]. Highly active infected monocytes migrate, reach the choriocapillaries and PE cells and secrete inflammatory mediators in response to damage. However, what exactly makes monocytic cells migrate from peripheral blood into the choriocapillary circulation is not completely clear. Conducted "antimacrophage" therapy (administration of drugs depleting circulating monocytes) leads to decrease in the size and activity of the neovascular membranes [70].

Historically, one of the first microorganisms suspected of forming chronic vascular pathology, was CMV - one of eight pathogenic members of the Herpesviridae family. In 1973 C. Fabricant et al. were the first who hypothesized the presence of the link of atherosclerosis with viruses of the human herpes group. The ability of viruses to disrupt lipid metabolism in endothelial cells of experimental animals and to induce deposition of cholesterol crystals in them, followed by the formation of an atherosclerotic plaque, was experimentally established [71]. This study served stimulus to further define of CMV- infections role in the development of such socially significant diseases as ischemic heart disease, acute coronary syndrome, Alzheimer's disease and AMD [72-75].

CMV is widespread in the human population. It is a ubiquitous virus with a prevalence of about $100 \%$ in both Africa and Asia, and 80\% in Europe and North America [76]. After the virus crosses the entrance gate (any mucous membranes), it spreads in the bloodstream to all organs [77]. CMV can lead to chronic latent infection, characterized by a paradoxical specificity - high levels of protective antibodies are combined with an asymptomatic actively multiplying virus. It is detected in different cellular structures (epithelial and endothelial cells, fibroblasts, neuroglial and muscle cells, leukocytes, macrophages) $[77,78]$. Due to the low pathogenicity and ability to suppress cellular immunity (due to long-term evolution and adaptation of the virus in the human body), healthy individuals have a lifelong persistence of CMV with periodic reactivation infection, usually occurring at the subclinical level [77, 79].

It should be noticed, that the reproduction of the virus usually occurs in endothelial cells, an inner surface of vessels which exists in each organ and tissue of the human body. As a result, CMV is able to penetrate into the cells of the parenchyma of any organ [77]. Role of CMV as a trigger of inflammation with the subsequent development of vascular pathology (atherosclerosis, vasculitis) was confirmed by many researchers [80-84]. Several authors suggested the possible involvement of $\mathrm{CMV}$ in the development of AMD and the transition of the dry form of the disease in the wet. They observed an increased titers of immuno-globulins $G$ (IgG) to CMV in blood serum in patients with age-related changes in the macula [75].

Various authors have attempted to find a link between chronic systemic CMV infection and the development of choroidal newly formed vessels in experimental studies in rodents. The participation of CMV-infected macrophages in the formation of the neovascular membrane was revealed in studies of S. Cousins et al. [85]. Various authors have attempted to find a link between chronic systemic CMV infection and the development of choroidal neovascularization in experimental studies in rodents. [85].

Another explanation for the role of CMV in the development of neovascularization is infection of the choriocapillary endothelium. Periodic activation of latent CMV infection can lead to infection of circulating monocytes and neutrophils, which act as "carriers" of infectious virions into endothelial cells [86]. Persistent infection of endothelial cells in their turn leads to attraction of macrophages to the lesion focus, their adhesion and cytokines synthesis. It promotes the onset or activation of neovascularization $[87,88]$.

The third possibility is that the influence of CMV on the development of neovascular AMD is associated with nonspecific immune stimulation. It is known that most persistent viral infections are characterized by a disruption of the cytokine network function [50]. The main chain in the pathogenesis of the long percistence of pathogens in the body consists of pronounced violations in the balance of the Th1 and Th2 pathways of the immune response and, therefore, dysregulation of production and interaction of secreted cytokines. Thus, CMV infection acts as an "adjuvant" in conjunction with others factors of AMD pathogenesis, causing excessive pro-inflammatory mediator production and launch immune inflammation in PE cells with active secretion of VEGF [89]. This theory is indirectly supported by the effectiveness of anti-inflammatory therapy in the treatment of wet AMD. [90]. Along with other diseases associated with age (atherosclerosis, Alzheimer's disease, coronary heart disease), in the pathogenesis of AMD, immune-inflammatory mechanisms are clearly traced, which have recently acquired the features of a sound scientific theory. Infectious agents, including cytomegalovirus, can play an important role in immunologically mediated inflammation in the development of various forms of AMD.

\section{The Connection Between SARS-CoV-2 and Diseases of the Posterior Pole of the Eyes}

During a pandemic of a new coronavirus (SARS-CoV-2) 
infection, the issue of pathogenesis, development of complications, prognosis and treatment becomes very relevant. Currently, there is no common understanding of the pathogenesis of this disease. Several authors describe the clinical manifestations of this viral infection. But if we suggest that the new coronavirus infection brings the same changes as cytomegalovirus (see the figure above), then it becomes clear which clinical manifestations can be expected. Hence, in our opinion, the main aspects of the pathogenesis of the novel coronavirus (SARS-CoV-2) infection are:

1. Thrombus formation with subsequent deposition of cholesterol (development of atherosclerotic lesions).

2. Ischemia (hypoxia) of the retina and brain tissue.

3. Fibrosis (for the eye, epiretinal fibrosis).

It is necessary to highlight that ophthalmologist was the first, who reported the virus in Wuhan and then died while treating a patient for glaucoma. Conjunctivitis is the most common manifestation and can develop at any stage of the disease [91]. However, the effects of SARS-CoV-2 are not limited to conjunctivitis, ocular manifestations are various and their pathogenesis is very compound.

Viral-host interactions can guide discovery of diseases. These interactions activate several immune pathways, including complement and coagulation, as targets of coronaviruses. According to literature, history of macular degeneration (due to complement-activation disorders) and history of coagulation disorders (thrombocytopenia, thrombosis and hemorrhage) are risk factors for SARS-CoV2-associated morbidity and mortality. Infection results in robust engagement of the complement and coagulation pathways. This confirms that eye can be a target of organ damage in SARS-CoV-2 infection [92]. However, the mechanism of such damage, the ocular manifestations of the disease, is poorly understood.

Thromboembolic complications due to COVID-19 has been well described in literature; however, reported eye manifestations of COVID-19 are limited. COVID-19 may predispose patients to thrombotic disease, both in the venous and arterial circulations, because of excessive inflammation, platelet activation, endothelial dysfunction, and stasis [93].

Microvasculature lesions may lead to a wide range of eye diseases. This is due to the fact that the retinal circulation is an end arterial system, which has a clinical significance because of the potentially vision-threatening nature of retinal vascular diseases.

SARS-CoV-2 infection leads to endothelial cell inflammation in several organs and tissues as a direct consequence of viral involvement and of the host inflammatory response. Apoptosis induction might have an important role in endothelial cell damage in patients with COVID-19 [94]. It occurs within vessels of any caliber and contributes to pathological events; including tissue hypoperfusion, injury, thrombosis and vascular dysfunction in the acute, subacute and possibly chronic stages of disease [94]. COVID-19-endotheliitis could explain the systemic impaired microcirculatory function and their clinical manifestations in patients with COVID-19 [95].
Central retinal vein occlusion is one of the many vascular manifestations of COVID-19. There are number of cases of this eye manifestation [96-100]. The mechanism responsible for COVID-19 thromboembolic events is still poorly understood, but may be due to excessive inflammation, hypoxia, immobilization [100]. Hypercoagulability is a major risk factor for CRVO. The case of ophthalmic artery occlusion (OAO) is also described in a young patient with COVID-19 infection who was on therapeutic anticoagulation with apixaban [101].

Neurological manifestations have been documented in almost $36 \%$ of the cases of COVID-19 [102]. They included dizziness, headache, anosmia, hypogeusia, Guillain-Barré syndrome (GBS), and ischemic stroke [91]. Reduction of smell and taste is recognized as one of the cardinal symptoms of COVID-19. The major hypothesis by now is genetic differences in the prevalence of chemosensory defects that may be caused by variations in the binding affinity of the ACE2 receptor for the virus and may dictate infectivity and spreading of the virus. Neurotropism of the virus has been proposed as one of the mechanisms for the neurological and neuro-ophthalmic manifestations.

Neuro-ophthalmic manifestations of COVID-19. 19 cases reported by March 2021 [92]. According to the literature, COVID-19 manifestations may include isolated inflammatory optic neuritis. It can lead to permanent visual acuity loss [103]. In this case, initial disc edema was moderate to mild, but it led to a severe atrophy. Unilateral optic neuritis without evidence of disseminated CNS involvement was also observed [104]. Confirming the relation between optic neuropathy and the persistence of the virus, these lesions were also described during varicellazoster virus infection [105].

K Sawalha et al. observed acute bilateral demyelinating optic neuritis. Authors believe, that COVID-19 infection has triggered patient's immune system to present these findings [106].

\section{Methods of Treatment of AMD [107]}

Most common and popular therapy of dry AMD form is complex of vitamins with antioxidant activity, lutein, zeaxanthin and zinc. The aim of such therapy is the prevention of pigment epithelium atrophy, new druses formation, lipofuscin deposition. A novel method of AMD treatment was connected with appearance of peptide bioregulators. They act like stimulators of protein synthesis and regulation of cellular metabolism. The most well-known and effective byopeptide is Retinalamin which is a complex of low molecular polypeptides (molecular mass from 1000 to 10000 daltons). This mass is able to penetrate through bloodocular barrier. Retinalamin acts like a stimulator of photoreceptors and retinal cells, it accelerates restoration processes of light sensitivity, improves the function of pigment epithelium and photoreceptors viability, stimulates reparative processes [108]. As for exudatine form of AMD, the main direction of the treatment is an impact on choroidal 
neovascularization and prevention of new vessels formation. A new era in treatment of neovascularization form of AMD has come with appearance of anti-VEGF agents and now they are the first choice methods. VEGF inhibitors role is in linking and inactivation of biologically active endothelial growth factor A (VEGF) and the growth of neovascular vessels. Previously wet form of AMD was treated by a photodynamic therapy. The method consists in the use of low-energy laser irradiation on the affected area of the retina after preliminary intravenous injection of verteporfirin. This leads to a photochemical decomposition of the drug, atomic oxygen release and endothelial cells damage, leading to occlusion of newly formed vessels [109]. Laser coagulation using in hemorrhagic stages of AMD leads to destruction of retinal tissues and scar formation. This damages fovea and reduces the number of patients in which such treatment is possible to be used. There are also three known surgical methods of treatment and two of them have doubtful possibility of a positive effect and may lead to serious complications. Thus, deleting of a neovascular membrane may cause choriocapillary atrophy; retinal translocation may also cause choriocapillary atrophy and proliferative vitreoretinopathy. Transplantation of pigment epithelial cells is still at the stage of experimental studies.

\section{Conclusion}

Thus, the individual scenario for the development of AMD in each person is determined by many factors: age-related changes in the vascular system and PE cells, genetic predisposition, lifestyle, dietary habits and metabolism, the degree of activity of chronic infections, immune response and many others, being, in fact, a polyetiological process [110]. In this regard, we can say with conviction: no single theory of the development of AMD can entirely explain the full diversity of pathological changes in of the retina and choroid tissues. Further study of the role of each factor of pathogenesis at all levels of the body's vital activity - from molecular to tissue will allow the development of fundamentally novel and perspective directions of AMD therapy.

Based on this literature review, the authors believe that there is much in common in the interaction with CMV carriage and new coronavirus infection. The main parallels are: 1 . the appearance of thrombosis, including the central retinal vein; 2. sharp ischemia of the brain tissue, including the retina and optic nerve; 3. Fibrosis (epiretinal fibrosis). It should be noted that symptoms mentioned above with a new coronavirus infection proceed rapidly and mutually burden each other. Another distinguishing feature of COVID-19 is often deaths while ophthalmological diseases has not been manifested. In future it seems possible a further increase in dystrophic diseases of the posterior pole of the eye (AMD), while maintaining a high rate of spread of coronavirus infection around the world. This requires further understanding of the pathogenesis and optimization of treatment methods. Comparison with manifestations of CMV infection can help us in studying the elements of pathogenesis in COVID-19.

\section{References}

[1] Flaxel, C., Adelman, R., Bailey, S., Fawzi, A., Lim, J., Vemulakonda, G., \& Ying, G. (2020). Age-Related Macular Degeneration Preferred Practice Pattern ${ }^{\circledR}$. Ophthalmology, 127 (1), P1-P65.

[2] Budzinskaja M. V., Gurova I. V. (2006). Subretinal neovascular membrane in age-related macular degeneration. Vestnik oftal'mologii, 122 (4): 49-54.

[3] Izmajlov A. S. (2001). Choroidal neovascularization. SanktPetersburg: SPbMAPO.

[4] Cruickshanks, K. (1997). The Prevalence of Age-Related Maculopathy by Geographic Region and Ethnicity. Archives Of Ophthalmology, 115 (2), 242.

[5] Tomany, S., Wang, J., van Leeuwen, R., Klein, R., Mitchell, P., \& Vingerling, J. et al. (2004). Risk factors for incident agerelated macular degeneration. Ophthalmology, 111 (7), 12801287.

[6] Seddon, J., Ajani, U., \& Mitchell, B. (1997). Familial Aggregation of Age-related Maculopathy. American Journal Of Ophthalmology, 123 (2), 199-206.

[7] Bikbov M. M., Fajzrahmanov R. R., Jarmukhametova A. L. (2013). Age related macular degeneration. Moscow: Aprel'; 2013.

[8] Gvetadze A. A., Koroleva I. A. Age-related macular degeneration. Modern look at the issiue. Review. Rossijskij Meditsinskij Zhurnal. Klinicheskaja oftal'mologija, 1: 37-41.

[9] Ryzhova L. S. (1991). The hemodynamics of the brain and eye in patients with presenile and senile nonexudative central chorioretinal dystrophy during health resort treatment. Vestnik oftal'mologii, 7 (6): 21-3.

[10] Vincent GK, Velkoff VA. The next four decades, the older population in the United States: 2010 to 2050. 2010; P25-1138. Available at: www.census.gov/prod/2010pubs/p25-1138.pdf. Accessed August 2021.

[11] Vit V. V. (2003). The structure of the human visual system. Odessa: Astroprint.

[12] Panova I. E., Prokop'eva M. Ju., Kinzerskij A. Ju., Sadretdinova E. R. (2007). Status of local hemodynamics in the initial stage of age-related macular degeneration. Kataraktal'naja i refrakcionnaja khirurgija, 7 (4): 32-6.

[13] Ramrattan, R. S., van der Schaft, T. L., Mooy, C. M., de Bruijn, W. C., Mulder, P. G., \& de Jong, P. T. (1994). Morphometric analysis of Bruch's membrane, the choriocapillaris, and the choroid in aging. Investigative ophthalmology \& visual science, 35 (6), 2857-2864.

[14] Prokop'eva M. Ju., Panova I. E., Kinzerskij A. Ju., Ermak E. M., Tonkikh N. A. (2006). Features of local blood flow in various forms of age-related macular degeneration. Vestnik Orenburgskogo gosudarstvennogo universiteta, S11 (61): 235-7. 
[15] Kiseleva T. N. (2004). Ul'trazvukovye metody issledovaniia krovotoka $\mathrm{v}$ diagnostike ishemicheskikh porazheniǐ glaza. Vestnik oftalmologii, 120 (4), 3-5.

[16] Krasnov M. M., Kuznetsova I. I. Ultrasonic dopplerography in the diagnosis of vascular eye diseases. Vestnik oftal'mologii. 1981; 97 (6): 26-7.

[17] Klettner, A., Kauppinen, A., Blasiak, J., Roider, J., Salminen, A., \& Kaarniranta, K. (2013). Cellular and molecular mechanisms of age-related macular degeneration: from impaired autophagy to neovascularization. The international journal of biochemistry \& cell biology, 45 (7), 1457-1467.

[18] Gvarishvili E. P. (1999). Using of pharmacological and physical treatment in the therapy of chorioretinal dystrophies: cand. dis. of med. sci. Moscow.

[19] Abdullaeva E. A. (2002). Pathogenetic therapy of central involute chorioretinal dystrophy: cand. dis. of med. sci. Ufa.

[20] Panormova N. V. (1983). Choroidal microcirculation in general vascular pathology. Morfologicheskie aspekty oftal'mologii.

[21] Baranov V. I., Golikov B. M. State of retinal hemodynamics in patients with primary arterial hypotension. Vestnik oftal'mologii, 1984; 100 (2): 50-3.

[22] Selitskaja T. I. (1977), Age-related macular degeneration and atherosclerosis. Oftal'mologicheskij zhurnal, 1: 50-2.

[23] Curcio, C. A., Johnson, M., Huang, J. D., \& Rudolf, M. (2009). Aging, age-related macular degeneration, and the response-to-retention of apolipoprotein B-containing lipoproteins. Progress in retinal and eye research, 28 (6), 393422.

[24] Olofsson, S. O., \& Borèn, J. (2005). Apolipoprotein B: a clinically important apolipoprotein which assembles atherogenic lipoproteins and promotes the development of atherosclerosis. Journal of internal medicine, 258 (5), 395-410.

[25] Beatty, S., Koh, H., Phil, M., Henson, D., \& Boulton, M. (2000). The role of oxidative stress in the pathogenesis of agerelated macular degeneration. Survey of ophthalmology, 45 (2), 115-134.

[26] Drobek-Słowik, M., Karczewicz, D., \& Safranow, K. (2007). Potencjalny udział stresu oksydacyjnego w patogenezie zwyrodnienia plamki zwiazanego $\mathrm{z}$ wiekiem (AMD) [The potential role of oxidative stress in the pathogenesis of the age-related macular degeneration (AMD)]. Postepy higieny $i$ medycyny doswiadczalnej (Online), 61, 28-37.

[27] Yildirim, Z., Ucgun, N. I., \& Yildirim, F. (2011). The role of oxidative stress and antioxidants in the pathogenesis of agerelated macular degeneration. Clinics (Sao Paulo, Brazil), 66 (5), 743-746.

[28] Kaneto, H., Katakami, N., Matsuhisa, M., \& Matsuoka, T. A. (2010). Role of reactive oxygen species in the progression of type 2 diabetes and atherosclerosis. Mediators of inflammation, 2010, 453892.

[29] Rodrigo, R., González, J., \& Paoletto, F. (2011). The role of oxidative stress in the pathophysiology of hypertension. Hypertension research: official journal of the Japanese Society of Hypertension, 34 (4), 431-440.

[30] Davies K. J. (1995). Oxidative stress: the paradox of aerobic life. Biochemical Society symposium, 61, 1-31.

[31] Rattan S. I. (2006). Theories of biological aging: genes, proteins, and free radicals. Free radical research, 40 (12), $1230-1238$.

[32] Valko, M., Leibfritz, D., Moncol, J., Cronin, M. T., Mazur, M., \& Telser, J. (2007). Free radicals and antioxidants in normal physiological functions and human disease. The international journal of biochemistry \& cell biology, 39 (1), 44-84.

[33] Hageman, G. S., Luthert, P. J., Victor Chong, N. H., Johnson, L. V., Anderson, D. H., \& Mullins, R. F. (2001). An integrated hypothesis that considers drusen as biomarkers of immune-mediated processes at the RPE-Bruch's membrane interface in aging and age-related macular degeneration. Progress in retinal and eye research, 20 (6), 705-732.

[34] Medeiros, N. E., \& Curcio, C. A. (2001). Preservation of ganglion cell layer neurons in age-related macular degeneration. Investigative ophthalmology \& visual science, 42 (3), 795-803.

[35] Haimovici, R., Gantz, D. L., Rumelt, S., Freddo, T. F., \& Small, D. M. (2001). The lipid composition of drusen, Bruch's membrane, and sclera by hot stage polarizing light microscopy. Investigative ophthalmology \& visual science, 42 (7), 15921599.

[36] Sparrow, J. R., Kim, S. R., \& Wu, Y. (2010). Experimental approaches to the study of A2E, a bisretinoid lipofuscin chromophore of retinal pigment epithelium. Methods in molecular biology (Clifton, N. J.), 652, 315-327.

[37] Eldred, G. E., \& Lasky, M. R. (1993). Retinal age pigments generated by self-assembling lysosomotropic detergents. Nature, 361 (6414), 724-726.

[38] Finnemann, S. C., Leung, L. W., \& Rodriguez-Boulan, E. (2002). The lipofuscin component A2E selectively inhibits phagolysosomal degradation of photoreceptor phospholipid by the retinal pigment epithelium. Proceedings of the National Academy of Sciences of the United States of America, 99 (6), $3842-3847$.

[39] Suter, M., Remé, C., Grimm, C., Wenzel, A., Jäättela, M., Esser, P., Kociok, N., Leist, M., \& Richter, C. (2000). Agerelated macular degeneration. The lipofusion component $\mathrm{N}$ retinyl-N-retinylidene ethanolamine detaches proapoptotic proteins from mitochondria and induces apoptosis in mammalian retinal pigment epithelial cells. The Journal of biological chemistry, 275 (50), 39625-39630.

[40] Kannan, R., Zhang, N., Sreekumar, P. G., Spee, C. K., Rodriguez, A., Barron, E., \& Hinton, D. R. (2006). Stimulation of apical and basolateral VEGF-A and VEGF-C secretion by oxidative stress in polarized retinal pigment epithelial cells. Molecular vision, 12, 1649-1659.

[41] Klettner, A., \& Roider, J. (2009). Constitutive and oxidativestress-induced expression of VEGF in the RPE are differently regulated by different Mitogen-activated protein kinases. Graefe's archive for clinical and experimental ophthalmology $=$ Albrecht von Graefes Archiv fur klinische und experimentelle Ophthalmologie, 247 (11), 1487-1492.

[42] Wu, W. C., Hu, D. N., Gao, H. X., Chen, M., Wang, D., Rosen, R., \& McCormick, S. A. (2010). Subtoxic levels hydrogen peroxide-induced production of interleukin- 6 by retinal pigment epithelial cells. Molecular vision, 16, 1864 1873. 
[43] Penn, J. S., Madan, A., Caldwell, R. B., Bartoli, M., Caldwell, R. W., \& Hartnett, M. E. (2008). Vascular endothelial growth factor in eye disease. Progress in retinal and eye research, 27 (4), 331-371.

[44] Boĭko, É. V., Churashov, S. V., \& Kamilova, T. A. (2013). Vestnik oftalmologii, 129 (2), 86-90.

[45] Byeon, S. H., Lee, S. C., Choi, S. H., Lee, H. K., Lee, J. H., Chu, Y. K., \& Kwon, O. W. (2010). Vascular endothelial growth factor as an autocrine survival factor for retinal pigment epithelial cells under oxidative stress via the VEGFR2/PI3K/Akt. Investigative ophthalmology \& visual science, 51 (2), 1190-1197.

[46] Hammond, C. J., Webster, A. R., Snieder, H., Bird, A. C., Gilbert, C. E., \& Spector, T. D. (2002). Genetic influence on early age-related maculopathy: a twin study. Ophthalmology, 109 (4), 730-736.

[47] Silvestri, G., Johnston, P. B., \& Hughes, A. E. (1994). Is genetic predisposition an important risk factor in age-related macular degeneration? Eye (London, England), 8 (Pt 5), 564568.

[48] Seddon, J. M., Cote, J., Page, W. F., Aggen, S. H., \& Neale, M. C. (2005). The US twin study of age-related macular degeneration: relative roles of genetic and environmental influences. Archives of ophthalmology (Chicago, Ill.: 1960), 123 (3), 321-327.

[49] Hageman, G. S., Anderson, D. H., Johnson, L. V., Hancox, L. S., Taiber, A. J., Hardisty, L. I., Hageman, J. L., Stockman, H. A., Borchardt, J. D., Gehrs, K. M., Smith, R. J., Silvestri, G., Russell, S. R., Klaver, C. C., Barbazetto, I., Chang, S., Yannuzzi, L. A., Barile, G. R., Merriam, J. C., Smith, R. T., ... Allikmets, R. (2005). A common haplotype in the complement regulatory gene factor $\mathrm{H}(\mathrm{HF} 1 / \mathrm{CFH})$ predisposes individuals to age-related macular degeneration. Proceedings of the National Academy of Sciences of the United States of America, 102 (20), 7227-7232.

[50] Rabson, A., Rabson, A., \& Delves, P. (2005). Really essential medical immunology. Blackwell Publishing.

[51] Zareparsi, S., Branham, K. E., Li, M., Shah, S., Klein, R. J., Ott, J., Hoh, J., Abecasis, G. R., \& Swaroop, A. (2005). Strong association of the $\mathrm{Y} 402 \mathrm{H}$ variant in complement factor $\mathrm{H}$ at $1 \mathrm{q} 32$ with susceptibility to age-related macular degeneration. American journal of human genetics, 77 (1), 149-153.

[52] Johnson, P. T., Betts, K. E., Radeke, M. J., Hageman, G. S., Anderson, D. H., \& Johnson, L. V. (2006). Individuals homozygous for the age-related macular degeneration riskconferring variant of complement factor $\mathrm{H}$ have elevated levels of CRP in the choroid. Proceedings of the National Academy of Sciences of the United States of America, 103 (46), 17456-17461.

[53] Penfold, P. L., Killingsworth, M. C., \& Sarks, S. H. (1985). Senile macular degeneration: the involvement of immunocompetent cells. Graefe's archive for clinical and experimental ophthalmology $=$ Albrecht von Graefes Archiv fur klinische und experimentelle Ophthalmologie, 223 (2), 69-76.

[54] Zeng, F., Zhang, M., Xu, Y., \& Xu, H. (2013). ARMS2 interference leads to decrease of proinflammatory mediators. Graefe's archive for clinical and experimental ophthalmology $=$ Albrecht von Graefes Archiv fur klinische und experimentelle Ophthalmologie, 251 (11), 2539-2544.
[55] Hooks, J. J., Chan, C. C., \& Detrick, B. (1988). Identification of the lymphokines, interferon-gamma and interleukin-2, in inflammatory eye diseases. Investigative ophthalmology \& visual science, 29 (9), 1444-1451.

[56] Cousins, S. W., Espinosa-Heidmann, D. G., \& Csaky, K. G. (2004). Monocyte activation in patients with age-related macular degeneration: a biomarker of risk for choroidal neovascularization? Archives of ophthalmology (Chicago, Ill.: 1960), 122 (7), 1013-1018.

[57] Kutty R. K., Nagineni C. N., Samuel W., et al. Differential regulation of microRNA-146a and microRNA-146b-5p in human retinal pigment epithelial cells by interleukin- $1 \beta$, tumor necrosis factor- $\alpha$, and interferon- $\gamma$. Molecular vision. 2013; 19: 737-50

[58] Ketlinskij S. A., Simbircev A. S. (2008). Cytokines. SanktPetersburg: Foliant.

[59] Ozaki, E., Campbell, M., \& Doyle, S. L. (2015). Targeting the NLRP3 inflammasome in chronic inflammatory diseases: current perspectives. Journal of inflammation research, 8, 1527.

[60] Doyle, S. L., Campbell, M., Ozaki, E., Salomon, R. G., Mori, A., Kenna, P. F., Farrar, G. J., Kiang, A. S., Humphries, M. M., Lavelle, E. C., O'Neill, L. A., Hollyfield, J. G., \& Humphries, P. (2012). NLRP3 has a protective role in agerelated macular degeneration through the induction of IL-18 by drusen components. Nature medicine, 18 (5), 791-798.

[61] Kauppinen, A., Niskanen, H., Suuronen, T., Kinnunen, K., Salminen, A., \& Kaarniranta, K. (2012). Oxidative stress activates NLRP3 inflammasomes in ARPE-19 cells-implications for age-related macular degeneration (AMD). Immunology letters, 147 (1-2), 29-33.

[62] Tarallo, V., Hirano, Y., Gelfand, B. D., Dridi, S., Kerur, N., Kim, Y., Cho, W. G., Kaneko, H., Fowler, B. J., Bogdanovich, S., Albuquerque, R. J., Hauswirth, W. W., Chiodo, V. A., Kugel, J. F., Goodrich, J. A., Ponicsan, S. L., Chaudhuri, G., Murphy, M. P., Dunaief, J. L., Ambati, B. K., ... Ambati, J. (2012). DICER1 loss and Alu RNA induce age-related macular degeneration via the NLRP3 inflammasome and MyD88. Cell, 149 (4), 847-859.

[63] Watanabe, K., Zhang, X. Y., Kitagawa, K., Yunoki, T., \& Hayashi, A. (2009). The effect of clonidine on VEGF expression in human retinal pigment epithelial cells (ARPE19). Graefe's archive for clinical and experimental ophthalmology $=$ Albrecht von Graefes Archiv fur klinische und experimentelle Ophthalmologie, 247 (2), 207-213.

[64] Nagineni, C. N., Kommineni, V. K., William, A., Detrick, B., \& Hooks, J. J. (2012). Regulation of VEGF expression in human retinal cells by cytokines: implications for the role of inflammation in age-related macular degeneration. Journal of cellular physiology, 227 (1), 116-126.

[65] Jonas, J. B., Tao, Y., Neumaier, M., \& Findeisen, P. (2010). Monocyte chemoattractant protein 1, intercellular adhesion molecule 1, and vascular cell adhesion molecule 1 in exudative age-related macular degeneration. Archives of ophthalmology (Chicago, Ill.: 1960), 128 (10), 1281-1286.

[66] Huang, H., Parlier, R., Shen, J. K., Lutty, G. A., \& Vinores, S. A. (2013). VEGF receptor blockade markedly reduces retinal microglia/macrophage infiltration into laser-induced CNV. PloS one, 8 (8), e71808. 
[67] Hahn, G., Jores, R., \& Mocarski, E. S. (1998). Cytomegalovirus remains latent in a common precursor of dendritic and myeloid cells. Proceedings of the National Academy of Sciences of the United States of America, 95 (7), 3937-3942.

[68] Slobedman, B., Mocarski, E. S., Arvin, A. M., Mellins, E. D., \& Abendroth, A. (2002). Latent cytomegalovirus downregulates major histocompatibility complex class II expression on myeloid progenitors. Blood, 100 (8), 2867-2873.

[69] Cinatl, J., Jr, Vogel, J. U., Kotchetkov, R., Scholz, M., \& Doerr, H. W. (1999). Proinflammatory potential of cytomegalovirus infection. specific inhibition of cytomegalovirus immediate-early expression in combination with antioxidants as a novel treatment strategy?. Intervirology, 42 (5-6), 419-424.

[70] Espinosa-Heidmann, D. G., Suner, I. J., Hernandez, E. P., Monroy, D., Csaky, K. G., \& Cousins, S. W. (2003). Macrophage depletion diminishes lesion size and severity in experimental choroidal neovascularization. Investigative ophthalmology \& visual science, 44 (8), 3586-3592.

[71] Fabricant, C. G., Krook, L., \& Gillespie, J. H. (1973). Virusinduced cholesterol crystals. Science (New York, N. Y.), 181 (4099), 566-567.

[72] Baranova E. G., Parkhomenko Ju. V., Sizikova O. N., Ivanov P. A., Krasnoperov V. G. (2006). Comparative analysis of total coronary lesions, dyslipidemia and the fact of infection with herpes simplex virus 1,2 types, cytomegalovirus in patients with coronary heart disease. Dal'nevostochnyj medicinskij zhurnal, 4: 5-7.

[73] Benditt, E. P., Barrett, T., \& McDougall, J. K. (1983). Viruses in the etiology of atherosclerosis. Proceedings of the National Academy of Sciences of the United States of America, 80 (20), 6386-6389.

[74] Fabricant, C. G., Fabricant, J., Litrenta, M. M., \& Minick, C. R. (1978). Virus-induced atherosclerosis. The Journal of experimental medicine, 148 (1), 335-340.

[75] Miller, D. M., Espinosa-Heidmann, D. G., Legra, J., Dubovy, S. R., Sũner, I. J., Sedmak, D. D., Dix, R. D., \& Cousins, S. W (2004). The association of prior cytomegalovirus infection with neovascular age-related macular degeneration. American journal of ophthalmology, 138 (3), 323-328.

[76] Cannon, M. J., Schmid, D. S., \& Hyde, T. B. (2010). Review of cytomegalovirus seroprevalence and demographic characteristics associated with infection. Reviews in medical virology, 20 (4), 202-213.

[77] Griffiths, P., Baraniak, I., \& Reeves, M. (2015). The pathogenesis of human cytomegalovirus. The Journal of pathology, 235 (2), 288-297.

[78] Jarvis, M. A., \& Nelson, J. A. (2007). Human cytomegalovirus tropism for endothelial cells: not all endothelial cells are created equal. Journal of virology, 81 (5), 2095-2101.

[79] Lombardi, G., \& Stronati, M. (2005). Infezione congenita da citomegalovirus [Congenital cytomegalovirus infection]. Minerva pediatrica, 57 (5), 213-227.

[80] O'Connor, S., Taylor, C., Campbell, L. A., Epstein, S., \& Libby, P. (2001). Potential infectious etiologies of atherosclerosis: a multifactorial perspective. Emerging infectious diseases, 7 (5), 780-788.

[81] Dal Canto, A. J., \& Virgin, H. W., 4th (2000). Animal models of infection-mediated vasculitis: implications for human disease. International journal of cardiology, 75 Suppl 1, S37S52.

[82] Prasad, A., Zhu, J., Halcox, J. P., Waclawiw, M. A., Epstein, S. E., \& Quyyumi, A. A. (2002). Predisposition to atherosclerosis by infections: role of endothelial dysfunction. Circulation, 106 (2), 184-190.

[83] Zhu, J., Nieto, F. J., Horne, B. D., Anderson, J. L., Muhlestein J. B., \& Epstein, S. E. (2001). Prospective study of pathogen burden and risk of myocardial infarction or death. Circulation, $103(1), 45-51$.

[84] Hsich, E., Zhou, Y. F., Paigen, B., Johnson, T. M., Burnett, M. S., \& Epstein, S. E. (2001). Cytomegalovirus infection increases development of atherosclerosis in Apolipoprotein-E knockout mice. Atherosclerosis, 156 (1), 23-28.

[85] Cousins, S. W., Espinosa-Heidmann, D. G., Miller, D. M., Pereira-Simon, S., Hernandez, E. P., Chien, H., Meier-Jewett, C., \& Dix, R. D. (2012). Macrophage activation associated with chronic murine cytomegalovirus infection results in more severe experimental choroidal neovascularization. PLoS pathogens, 8 (4), e1002671.

[86] Gerna, G., Percivalle, E., Baldanti, F., Sozzani, S., Lanzarini, P., Genini, E., Lilleri, D., \& Revello, M. G. (2000). Human cytomegalovirus replicates abortively in polymorphonuclear leukocytes after transfer from infected endothelial cells via transient microfusion events. Journal of virology, 74 (12), $5629-5638$

[87] Knight, D. A., Waldman, W. J., \& Sedmak, D. D. (1999). Cytomegalovirus-mediated modulation of adhesion molecule expression by human arterial and microvascular endothelial cells. Transplantation, 68 (11), 1814-1818.

[88] Cebulla, C. M., Miller, D. M., Knight, D. A., Briggs, B. R., McGaughy, V., \& Sedmak, D. D. (2000). Cytomegalovirus induces sialyl Lewis (x) and Lewis ( $\mathrm{x}$ ) on human endothelial cells. Transplantation, 69 (6), 1202-1209.

[89] Panova I. E., Tonkih N. A., Prokop'eva M. Ju., Bukhtijarova N. V. (2004). Age-related macular degeneration with neovascular response: clinical features, characteristic of cellmediated immunity. Vestnik Orenburgskogo gosudarstvennogo universiteta, 5: 124-6.

[90] Wyględowska-Promieńska, D., Piotrowska-Gwóźdź, A., Piotrowska-Seweryn, A., Mazur-Piotrowska, G., \& Rokicki, W. (2014). Combination of bevacizumab and bromfenac therapy in age-related macular degeneration: a pilot study. Medical science monitor: international medical journal of experimental and clinical research, 20, 1168-1175.

[91] Sen, M., Honavar, S. G., Sharma, N., \& Sachdev, M. S. (2021). COVID-19 and Eye: A Review of Ophthalmic Manifestations of COVID-19. Indian journal of ophthalmology, 69 (3), 488-509.

[92] Ramlall, V., Thangaraj, P. M., Meydan, C., Foox, J., Butler, D., Kim, J., May, B., De Freitas, J. K., Glicksberg, B. S., Mason, C. E., Tatonetti, N. P., \& Shapira, S. D. (2020). Immune complement and coagulation dysfunction in adverse outcomes of SARS-CoV-2 infection. Nature medicine, 26 (10), $1609-1615$. 
[93] Bikdeli, B., Madhavan, M. V., Jimenez, D., Chuich, T., Dreyfus, I., Driggin, E., Nigoghossian, C., Ageno, W., Madjid, M., Guo, Y., Tang, L. V., Hu, Y., Giri, J., Cushman, M., Quéré, I., Dimakakos, E. P., Gibson, C. M., Lippi, G., Favaloro, E. J., Fareed, J.,... Global COVID-19 Thrombosis Collaborative Group, Endorsed by the ISTH, NATF, ESVM, and the IUA, Supported by the ESC Working Group on Pulmonary Circulation and Right Ventricular Function (2020). COVID-19 and Thrombotic or Thromboembolic Disease: Implications for Prevention, Antithrombotic Therapy, and Follow-Up: JACC State-of-the-Art Review. Journal of the American College of Cardiology, 75 (23), 2950-2973.

[94] Becker R. C. (2020). COVID-19 update: COVID-19associated coagulopathy. Journal of thrombosis and thrombolysis, 50 (1), 54-67.

[95] Varga, Z., Flammer, A. J., Steiger, P., Haberecker, M., Andermatt, R., Zinkernagel, A. S., Mehra, M. R., Schuepbach, R. A., Ruschitzka, F., \& Moch, H. (2020). Endothelial cell infection and endotheliitis in COVID-19. Lancet (London, England), 395 (10234), 1417-1418.

[96] Raval, N., Djougarian, A., \& Lin, J. (2021). Central retinal vein occlusion in the setting of COVID-19 infection. Journal of ophthalmic inflammation and infection, 11, 10.

[97] Walinjkar, J. A., Makhija, S. C., Sharma, H. R., Morekar, S. R., \& Natarajan, S. (2020). Central retinal vein occlusion with COVID-19 infection as the presumptive etiology. Indian journal of ophthalmology, 68 (11), 2572-2574.

[98] Sheth, J. U., Narayanan, R., Goyal, J., \& Goyal, V. (2020). Retinal vein occlusion in COVID-19: A novel entity. Indian journal of ophthalmology, 68 (10), 2291-2293.

[99] Invernizzi, A., Pellegrini, M., Messenio, D., Cereda, M., Olivieri, P., Brambilla, A. M., \& Staurenghi, G. (2020). Impending Central Retinal Vein Occlusion in a Patient with Coronavirus Disease 2019 (COVID-19). Ocular immunology and inflammation, 28 (8), 1290-1292.

[100] Yahalomi, T., Pikkel, J., Arnon, R., \& Pessach, Y. (2020). Central retinal vein occlusion in a young healthy COVID-19 patient: A case report. American journal of ophthalmology case reports, 20, 100992 .

[101] Dumitrascu, O. M., Volod, O., Bose, S., Wang, Y., Biousse,
V., \& Lyden, P. D. (2020). Acute ophthalmic artery occlusion in a COVID-19 patient on apixaban. Journal of stroke and cerebrovascular diseases: the official journal of National Stroke Association, 29 (8), 104982.

[102] Tisdale, A. K., \& Chwalisz, B. K. (2020). Neuro-ophthalmic manifestations of coronavirus disease 19. Current opinion in ophthalmology, 31 (6), 489-494.

[103] François, J., Collery, A. S., Hayek, G., Sot, M., Zaidi, M., Lhuillier, L., \& Perone, J. M. (2021). Coronavirus Disease 2019-Associated Ocular Neuropathy With Panuveitis: A Case Report. JAMA ophthalmology, 139 (2), 247-249.

[104] Rodrigo-Armenteros, P., Uterga-Valiente, J. M., Zabala-DelArco, J., Taramundi-Argüeso, S., Antón-Méndez, L., GómezMuga, J. J., \& Garcia-Monco, J. C. (2021). Optic neuropathy in a patient with COVID-19 infection. Acta neurologica Belgica, 1-3.

[105] Kedar, S., Jayagopal, L. N., \& Berger, J. R. (2019). Neurological and Ophthalmological Manifestations of Varicella Zoster Virus. Journal of neuro-ophthalmology: the official journal of the North American Neuro-Ophthalmology Society, 39 (2), 220-231.

[106] Sawalha, K., Adeodokun, S., \& Kamoga, G. R. (2020). COVID-19-Induced Acute Bilateral Optic Neuritis. Journal of investigative medicine high impact case reports, 8 , 2324709620976018.

[107] Ignatiev S. A, Alekseev I. B, \& Nam Ya. A. (2018). Military and Medical Expertise in Patients with Central Retinal Degeneration. International Journal Of Clinical And Experimental Medical Sciences, 4 (4), 68.

[108] V. K. Khavinson, S. V. Trofimova. (2000). Peptide bioregulators in ophthalmology. Saint Petersburg: Foliant.

[109] Stolyarenko G. Y., Tyurina M. I, Khalaym A. V. (2006). "Invasive therapy of the pathology of the macular area of the retina", Macula: Thesis in collection of reports in the II All Russian seminar - "round table". Rostov-on-Don. pp. 379-380.

[110] Ignatyev S. A., Alekseev I. B., Chernakova G. M., Kleshcheva E. A., \& Nam Yu. A. (2015). Age-related Macular Degeneration and the Cytomegalovirus: Controversial Issues of Pathogenesis. Russian Ophthalmological Journal, 4, 71-78. 